\title{
DETECTION OF OXYTETRACYCLINE HYDROCHLORIDE RESIDUES AND EFFECT OF BOILING IN COW'S MILK
}

\author{
Mona, O. Abou El NIl; Thanae, M. Amin \\ and Ahmed, s. E. Aylad \\ Department of Food Hyglene Arimal Health Research Instilulc Dokl, Gi(x;1
}

\begin{abstract}
A tocat of twenty breed cous with clinical signs of respiratary disease alid iushlit fram duferent farms in Alexandria city were involued in this study. Oxytetracyclin Hydrochlortde (OTC) IPfizer Egypt) vyected intramuscular as a therapeutic doser of 20 ng/ $\mathrm{kg}$ body weight for three successive days. Milk samples were collected inmedintely be. fore first dnig admintstration and then oher 24,48,72,96,120,144,168, 216, 264, 312, 360, 408 and $456 h$. .

All milk samples showed posithe results for presence of (OTC) 24hs, after first dose with concentratton walue $3.05 \pm 0.86 \mathrm{mg} / \mathrm{mil}$ of $\mathrm{mllk}$ and the concentration ticreased at $49.72,96 \mathrm{hr}$ then the level lowered 120 to $408 \mathrm{hr}$. hll not detected at $456 \mathrm{hr}$.

As a result of bolling of muk samples at $1000 \mathrm{C}$ for 10 munutes (OTC) residues de stroyed by heat lis level significant decreased to $2.693 \pm 0.61 \mathrm{mg} / \mathrm{ml}$ after first dixy from administration with reduction rate (13.8) then lowered signyicantiy wik RR 130.5 . 78.9, 81.2, 80.4. 79.3.92.91 at 48,72, 96.120 and $144 \mathrm{hr}$. froin first dose as a result of bolling (OTCl lewel not detected from 216 tr tull end of experinient with reduction rat 100\%.

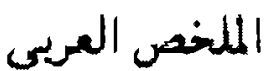

$$
\begin{aligned}
& \text { الكنيف عن بقايا الأوكسي تتراسيكلين هيلروكلوريد فى ألبان الأبقار وتأثير الغليان علبها } \\
& \text { مينى عمرأبوالنيل ينا محمد أمين أحمد صلاح الدين عباد }
\end{aligned}
$$

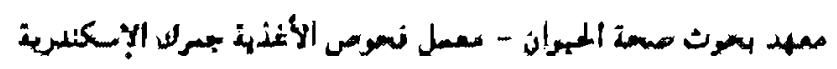

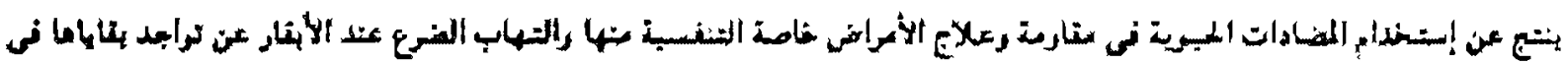




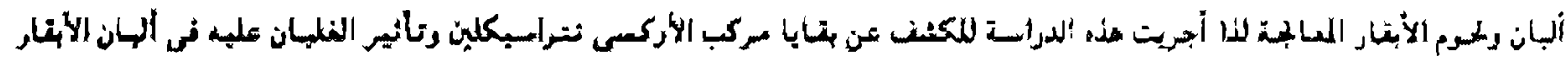

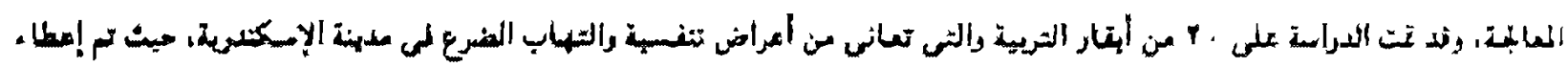

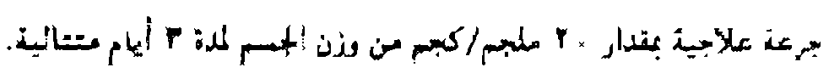

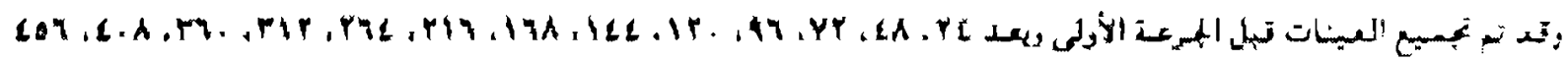

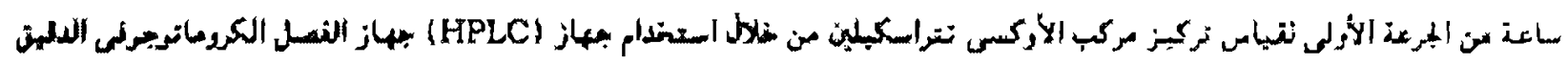

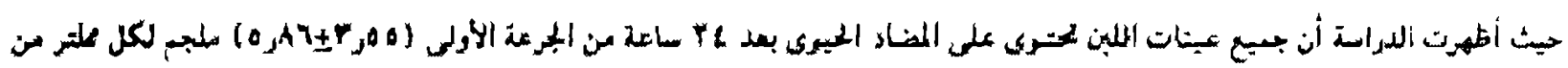

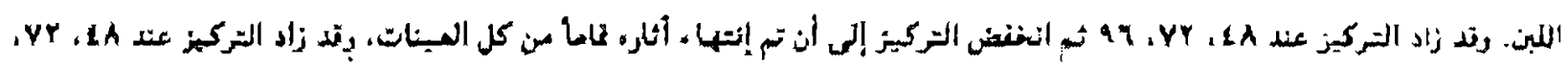

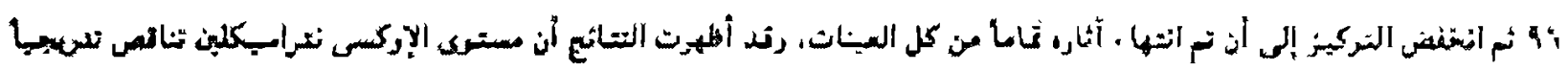

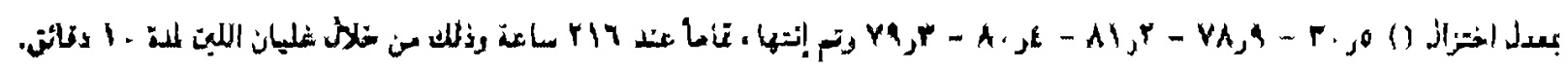

\section{INTRODUCTION}

In most of the livestock production system. antiblotic are usually used for the prevention and treatment or anlmal diseases and to $\mathrm{lm}$ prove the eflicacy of animal production (Dipealu, Along 2002 and Dlna, Arowolo, 1891). The most serlous objectuons to the presence of drug residues in food intended for human consumption arise as a consequence of human health considerations. With the extensive use of drugs in animals producthon, resldues of the parent drug and/or metabolites have a high potenual to be present in the edible animal products. The public health slgnificance of such adulteration of food supply is determined mainly by the level of the residues and individual drugs they are originated from (Botsoglou and Fletouria, 2001).

Antublotic represent the mosi Important group of exogenous inhibitory factors in milk. The most common being tetracyclines antiblotic are produced by Streptomyces spp. Is known as broad-spectrum antiblotic with a bactertostatic effect (Pavitna, ef al. 200\%).
Oxytetrocycline has good actwity againat acute diseases cause by gram-positso ethct gram-negative bactería. Included sptrocluct species. Actinomyces spectes and myco plas. ma species. The antumerobial drug wislcly used for the ureatment of many acute diseascs In cows, sheep and goal. like Oxytetracycline are likely to be lin as residues in milk or meat. Long acting formulation is an alternatwe to diseases therapy which normally iequire two or three dally parental treatment to maintain an eficacy level of anubiotic and to prolong is clrculating antiblotic concentration of the netIng agent.

Antiblotic restiducs had grcat side effects on public health which cause circinosenirity. Thomas, (1994) suggested that therc is it elose association between antibiotic restucs in lood and breast ceucc 7 . Gnilade and Babatude (1996) declared that tetracycline" res: dues was suspected to be carcinogenks by re. action with nitrile producing nitrosammie. One study explained the mechanism of sarcinogenteity of antlbiotic rcsidues via damaged DNA may amplify the abnomthality of (Brookets, 2980). 
Clnbb (1080) revealed that severed antiblothe residues has immunosuppression effect in human by Interference with phagocytosis and immunoglobalin synthesis beside elimination of antgen.

Contunuous injection of milk or dalry products with high or even low doses of antibiotic realdueg mught induce emergency reslatant strains of microorganism drug resistance has a deflulte complication factor in medical treatment expecially young chlldren (Martin ot al. 1096 and FAO/WHO, 1099).

Recent studles ouggested that contaminatlon of milk with a little antiblotic residues inholt starter cultures of cheeses fermented dairy products. interfere with acid production. a high molsture content which results in poor quality body and texture, rapid proteolysls and of flevour (Jeasen, 1096, Heegchen a Farding 1095 and Fubbert et al, 1906).

Eurittu et al. (2002) uged a lumineacent Escherichia coll straln for the speciflc detecton of tetracycline residues in raw borlne milk. The detection inits for tetracycifne. oxytertracycline, chlortetracycline, doxycline. methacycline, democlocycline were between 2 and $35 \mathrm{mg} / \mathrm{ml}$.

Analyzed (OTC) by Capolongo et al. (2002) th edible tlssues imuscle. Liver, and kddney). of 18 turkeys were determined after continuous administratton of the drug for 3 days in drinktng water at maximum recommended concentration of $400 \mathrm{mg} / \mathrm{L}$ by using metal chelate afflnity chromatography. They reported that after 1 day of withdrawal. OTC restdues were detected in muscle and liver af- ter 3 days after end of treatment.

Uno, (2002) studied the tissue distribution and residues depletion of forCl and oxolante acid (OA). The author concluded that. residu. al (OTC) was reduced to $50-70 \mathrm{ug} / \mathrm{m}$ il in muscles by usual method of cooking, baking and frying. These results conflrm that the cooking procedure could only reduce but not completely eliminate these drug residues in prawn.

The purpose of this study was to determine the presence of (OTC) oxytetracycline residues in milk from cows with clinical signs of resplratory and mastuts disease. being treated with (OTC). Milk sample were tested for (ortc) resldues within the whole pertod of antbiotic intra muscular treatment (3d) as well as pertod after drug administration. In order to deternilne (orC) residues in milk and also. to compare the effect of bolling of milk on these residues. HPLC method were used.

\section{MATERIAL AND METHODS}

Twenty brecd cows with clinical signs of resplratory diseases and mastlels from different farms in Alexandria clty were involved in this study.

oxytetracycline hydrochlorlde (OTC) long acting (Pfizer Egypt) injected Intrainuscular at does of $20 \mathrm{mg} / \mathrm{kg}$ body weight for three successive days.

Milk samples were collected immediately before the first drug administration $(0 \mathrm{hr})$ and then alter $124,48,72,96,120,144,168,216$. $264,312,408$ and $456 \mathrm{hr}$ ) the whthdrawal perlod of OTC is 5 days. 
Equal volumes of fore milk from eaeh quarter of the arme cow were taken durng milking In the morning and in the aftermoon and then mixed together, each gample was elassifled into 2 portion one part for deteetion of (OTC) residuea and other part were bolled at $1100^{\circ} \mathrm{Cl}$ for 10 minutes.

\section{Machod}

Oxytetracycline restdues in milk samples. were detected aecording to Jurunee, (2002) using high performanee llquid chromatography (HPLC).

\section{Rongont}

I. Standard oxytetracycltne $100 \%$.

II. Oxytetracycline hydrochloride pur. chased (PRzer Egypu.

III. Solvents:

a- A cetonitric and methanol wcre HPLC grade.

b- Mellvaine-EDTA-NACl buffer prepared acconding to the method (AOAC, 1997)

$\because$ (1997).

\section{Apparatus}

a- Reirigeratung centrifuges, (Ijniversal 16R. Hettich Germany).

b- Vortex mixer (model G 6560 8. Genle scientiftc USAS.

c- Water bach (model PEDIIS, WTB BIneler. Germany).

d- Thermocouple.

e- High performance liquld chromato. graph eonsists of a spertral system bynary pump modcl P2000, vacuum membrane Pegasser. Aspecteral Detector model UV 2000 at 350 Rheodync 7125 sampling valve with a loop and a computer for control and handing.

\section{RESULTS AND DISCUSSION}

The results of HPLC analysts shown in $\mathrm{Ta}$. ble (1). Fig. (1), revealed that all milk samples give positive results for presenee of (OTC) resi. dues twenty-four hours after first dose of drug administration. $[3.05 \pm 0.86 \mathrm{mg} / \mathrm{ml}$ of $\mathrm{mllk}]$ hourever average (OOTCl concentration in milk increased at $(48.72 .96 \mathrm{hr})$ from irst dose with mean value of $(4.60 \pm 0.90,11.12 \pm 0.82$ and $11.6 \pm 1.24 \mathrm{mg} / \mathrm{ml}$ of milk. Then. (urc) level lowered at 120,144,168,216,264,312,360and 408 from first dose tul not detected at $456 \mathrm{hr}$. with respectively mean values $18.31 \pm 0.96$, $4.03 \pm 1.01,3.32 \pm 2.02,2.73 \pm 1.75,1.66 \pm 1.06$, $1.08 \pm 0.68,0.65_{ \pm 0} 0.39,0.56 \pm 0.32 \mathrm{mg} / \mathrm{ml}$ of milk. Form Table (1), Figs. (1,2,3) the highest concentration level was observed at $96 \mathrm{hr}$ arter beginning of therapy (withdrawal time 5 days). Our results were Inagreement with that of Pavlina, et al. (2003) who reported that the highest average concentration of 195.86 ing OTC $\mathrm{mg} \mathrm{kg}$ was detected by HPLC mcthod 5 days after the first drug administration. Jarumee (2002), reported that all milk sam. ples showed positive results for presence of antiblotic restdues (OTC) twency four hours $(7,3 \mathrm{mg} / \mathrm{ml})$ after first drug administration and showed the highest concentration level at 96-120 hr (withdrawal 5 days). Cinquina et al. 2007 reported that the unthdrawal thme for long acting (OTC) in goat ( 6 days) and in sheep milk (7 days).

Dinemore of al (1096) revesicd that (OTC) was detected in milk of all cases dunng treatment at maxdmum concentration ranging from 47 to $1.800 J 91 . \mathrm{kg}$ (ppb). ruination of (Ond) residues after the last infusion ranged from zero to 44 hours (6 days). milk obtalned from cows that are treated for retained retal 
membranes by intra uterine fnfusion of (OTC) may contaln the drug for vartables lengths of tume. Mulk should be discarded to avold lllegal residues.

Rulo, et al. (2001) determined the two commerclal preparations of axytetracycline (OTC) the pharmacoklnetic behaviour, the presence of detectable milk residues and the penetration of milk of OTC administered by intravenous (IN) and Intramuscular (IM) routes in goats producing milk. The authors concluded that the presence of detectable residues In milk indicates that mulk should not be ueed for human consumption for 2 and 3 days after administration of canventlonal and long acting formulations, respectively.

Bchollbaum (1900) Investigated the fae tore responstble for antibiotic contamination of milk he found that $59 \%$ and $41 \%$ of tested samples due to post secretion and secretory contamination, respectively. Both (1082) observed that the use of intrmamary infusion antiblotdes constituted 929 of secretary contarnination. Treatment of mastltic cases with penvellin G intramammary assoclated withdrawal tume ranged from 2-18 days due to slow elimunation of antiblotic by certain lactating cases.

Eurel et al, (1082) noticed that quantitative detection of pericllin in bulk milk samples $(0.025-3-1 / \mathrm{u} / \mathrm{ml})$ was more than those oblained from Individual

Jecques at al. (1908) reported that one of 973 milk sample was suspect for tetracycline resldues by means of $B$. Calldolacts tube tes as well as by the receptor assay $B$ other sam- ples were also considered to be posiliwe.

Bolling it is of some interest to fletcontme if resldues of antbilotic can be destroyed by cooking procedures. The effect of heating il $100^{\circ} \mathrm{C}$ for $10 \mathrm{~min}$. on oTC regldues wals shown In Table (2): Fig. $[1,3\}$.

Our result showed that there were slgnificant deference at $(p<0.05)$ between non heat. ed and heated samples. OTC concentration in heated milk was $(2.63 \pm 0.61 \mathrm{mg} / \mathrm{mll}$ of milk after $24 \mathrm{hr}$ from drug administratlon witl: reduction rat $13.8 \%$. Level of (ORC) residue was $3.2 \pm 0.83$ at $48 \mathrm{hr}$ and $2.62 \pm 0.44$ at $72 \mathrm{hr}$. $2.31 \pm 0.32$ at $96 \mathrm{hr}$ after bofling with inghly signiffeant reduction rat (RR) 30 5. 78.9. 81.2. respectively. Level wo decreased to $1.63 \pm$ 0.35 at $120 \mathrm{hr}, 90.0 \pm 0.54$ and $0.22 \pm 0.13$ at 144 and $198 \mathrm{hr}$. Lll not detected at $216 \mathrm{hr}$. from first day of drug administration, with signiffcant reduction rate $(80.4,79.3,92.9)$ Table (2), Fig. (A).

A few reports have been published about the effect of heatng on the stablity of OTC in milk. Jarunee, (2002) evoked that there werc signiflcant delerence in (OTC). (TC) concentra ton as a result of milk healed to $63^{\circ}$ for 30 minutes with reduction rate of [OTCI spiked in mtlk at 200-300 ppb wexe 86.77 and 19.63 respectively and OIC was Complectly reduced by $190 \mathrm{~min}$. at $71^{\circ} \mathrm{C}$ indicating that lonker heat or sever bcating was required to reduce anublotic residues in intlk.

(OTC) are slmular to other antlblotics in their distribution and activity, Schelbner (1972) concluded that high concentration of pentellin $G$ and oxytetracycline were com. 
pletely in activated by an hour heating at $200^{\circ}$.

E-6herbinl, al. (2003), showed that thermal degradation of pentcillin by pasteur. zation (63\% $/ 30 \mathrm{~min})$, bolling $\left(100^{\circ} \mathrm{C} / 5 \mathrm{~min}\right)$ and sterkations $121{ }^{\circ} \mathrm{C} / \mathrm{m} / \mathrm{n}$ were $40 \%, 60 \%$ and $91 \%$ respectively.

The rate of Inactivation of anublotic by heat and pasteurtzation nearly simllar that was reported by Konecy (1978). Other tnvesugators found that thermal inaetivation rate of pentcilin ranged from 8 to $26.5 \%$ (Troptlo et al., 1985 and Abd El-Allm et al.. 1994). On the other hand rew studles coneluded that penictlin was not in activated by pasteurizatoon ơr drying.

Mdel and Wwam, (1994): Reported that when meat was packed in a sausage casing and cookdry in bolling water, (OTC) was reduced $95 \%$ in 30 minutes. Microwave cooking to well done (no red color) nequired of minutes gave a Anal temperature $98-102^{\circ}$ and reduced level 60\% from control. Frying required $8 \mathrm{~min}$ utes with inal tcmpcrature $81^{\circ} \mathrm{C}$ residues reduced to $17.3 \%$. Degeneration was related to nnal ternperaturc reached, which was higher from microwave cooking or for bolling than for frylng.

Our result of themal inactivatton or antubiothe by bolling nearly similar those reported by Hamann et al., (1978). They ubstived that boilling was inactivated pernicillin with liggl percentage $(65 \%)$ a lower percenlake of ther. mal inactivation was stated by tropilo et al., (1885).

Administraion of antiblotic w tactiting cows for treatment or prophylaxis lead to transferring of drug restdues or their metabulites to human through consumption of contaminated milk or dalry products. These antlbloucs may be found as it is or may present as metabolites with a modificd strueture arsel quil different in pharmaco-toxtcological properues of antublotlc. Tetracyclines mainly ab. sorbed from upper small Intestine. Diwateni calclum of milk and darry produces incerfep't with thelr absorption. As a result of chelition with calclum they tend to be deposited in the growth zone of teeth causing unpleasant pigsmentation filuorescence, yellow. brown discol. ouration).

This result algo suggested that bolling for $10 \mathrm{~min}$, of milk could caused a reduction of drug residue but it did not completely eliminated.

Shahand (1097). studled heat stability of drug residues in milk and reported that orc was less heat stable than CTC and ljoth were not completely reduced by $30 \mathrm{~min}$. al 62 and $71^{\circ} \mathrm{C}$ only $23.6-35.6 \%$ reduction for OCT. 
Table (1): Oxyte(racycline residues (mg/mi of milk) in cow's milk after intramuscular administration ar g dose of (20 ing/Ke B.tV.) fot three successive days,

\begin{tabular}{|c|c|c|c|}
\hline \multirow{2}{*}{ Period ufter OTC Administration } & \multicolumn{3}{|c|}{ Before bolling } \\
\hline & $\overline{\min }$ & $\max$ & MeantS.E \\
\hline $24 \mathrm{hr}$. & 1.561 & 4.541 & $3.05 \pm 0.86$ \\
\hline $48 \mathrm{hr}$. & 2.96 & $6 \times 045$ & $4.60 \pm 0.90$ \\
\hline $72 \mathrm{hr}$. & 9.706 & 12.53 & $11.12 \pm 0.82$ \\
\hline $96 \mathrm{hr}$. & 9.89 & 14.01 & $11.61 \pm 1.24$ \\
\hline $120 \mathrm{hr}$. & $6.6 x$ & 9.96 & $8.31 \pm 0.96$ \\
\hline $144 \mathrm{hr}$. & 2.28 & 5.79 & $4.03=1.01$ \\
\hline $169 \mathrm{hr}$ & 0 & 5,982 & $3.32=2.02$ \\
\hline $216 \mathrm{hr}$ & 0 & 5.99 & $2.73 \pm 1.75$ \\
\hline 264 hr. & 0 & 3,643 & $1.66 \times 1.06$ \\
\hline $312 \mathrm{hr}$ & 0 & 2.32 & $1.08 \div 0.68$ \\
\hline $360 \mathrm{hr}$ & 0 & 1.345 & $0.05 \pm 0.39$ \\
\hline $408 \mathrm{hr}$. & 0 & 1.09 & $0.56 \pm 0.32$ \\
\hline $156 \mathrm{hr}$ & 0 & 0 & $0 \pm 0$ \\
\hline
\end{tabular}

Table (2): Etfect or bolting an cetracycline residue (mg/ml of milk after intramuscular administration at dese of (20 mg/kg B.W) for three successlve days,

\begin{tabular}{|c|c|c|c|c|c|}
\hline \multirow{2}{*}{$\begin{array}{l}\text { Period afrer OTC } \\
\text { Adralnistration }\end{array}$} & \multicolumn{3}{|c|}{ Anter bolling } & \multirow{2}{*}{ R.R. } & \multirow[b]{2}{*}{ P-lest } \\
\hline & $\min$ & $\max$ & MeantS.E & & \\
\hline $24 \mathrm{hr}$. & 1.57 & 3.59 & $2.63 \pm 0.61$ & 13.8 & 1.696 \\
\hline $48 \mathrm{hr}$. & 1.763 & $4, \overline{63}$ & $3.20 \pm 0.83$ & 30.5 & $11.977^{\circ}$ \\
\hline $72 \mathrm{br}$. & 2.031 & 3.469 & $2.62 \pm 0.44$ & 78.9 & $20.149 *$ \\
\hline $96 \mathrm{hr}$. & 1.92 & 2.95 & $2.31 \pm 0.32$ & 81.2 & $10.136^{* *}$ \\
\hline $120 \mathrm{hr}$. & 1.021 & 2.239 & $1.63 \pm 0.35$ & 80.4 & $11.056^{* \prime \prime}$ \\
\hline $144 \mathrm{hr}$ & 0 & $1 \times 864$ & $0.90 \pm 0.54$ & 79.3 & $6.574^{\circ}$ \\
\hline $168 \mathrm{hr}$. & 0 & 0.450 & $0.22 \pm 0.13$ & 92.9 & 1.640 \\
\hline $216 \mathrm{hr}$ & 0 & 0 & $0 \pm 0$ & 100 & 1.558 \\
\hline $264 \mathrm{hr}$ & 0 & $\overline{0}$ & $0 \pm 0$ & 100 & 1.562 \\
\hline $312 \mathrm{hr}$. & 0 & 0 & $0 \pm 0$ & 100 & 1.602 \\
\hline $360 \mathrm{hr}$. & 0 & 0 & $0 \pm 0$ & 100 & 1,668 \\
\hline $408 \mathrm{hr}$ & 0 & 0 & $0 \pm 0$ & 100 & 1.768 \\
\hline $456 \mathrm{hr}$. & 0 & 0 & $0 \times 0$ & 0 & 0 \\
\hline
\end{tabular}

\footnotetext{
- Slatistically significant of $p<0.05$ "Statistically significant al $p<0.01 \quad$ R.R: Retiuction rat.
} 
Mona, O. Abou El Nil; et al...

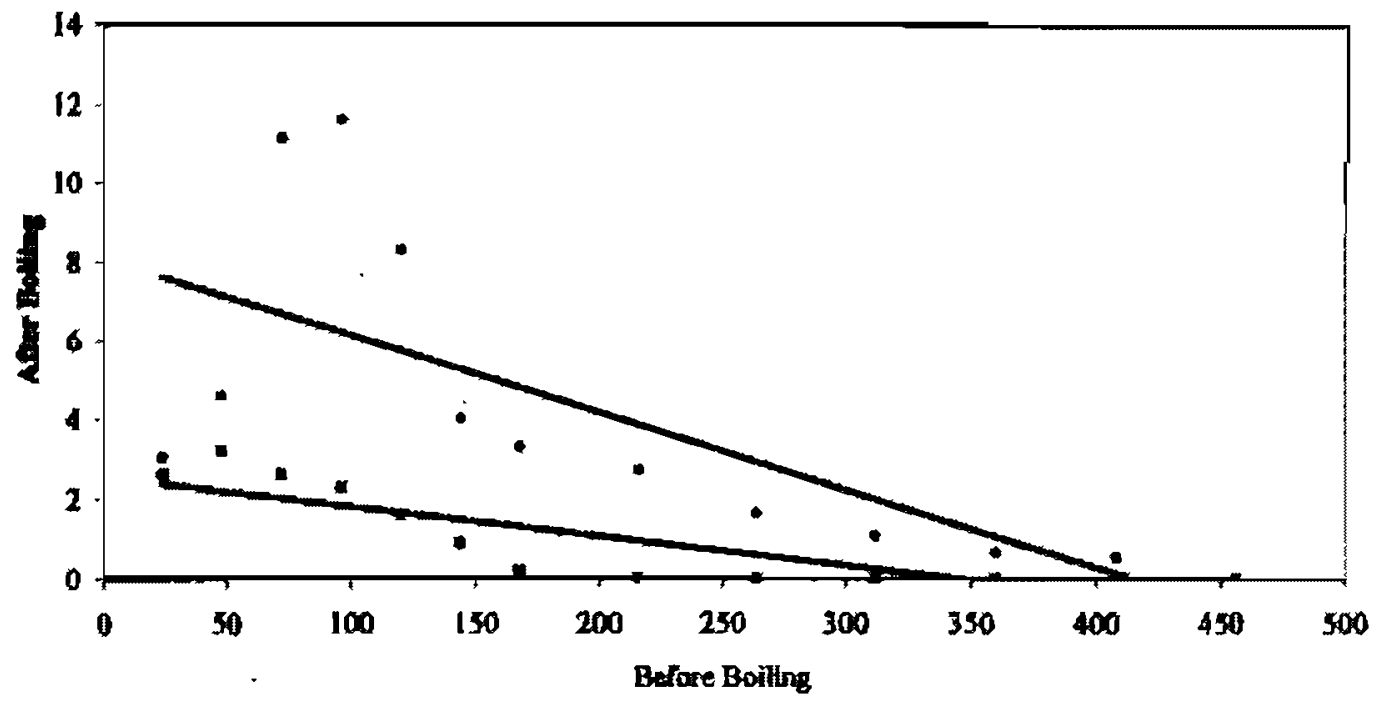

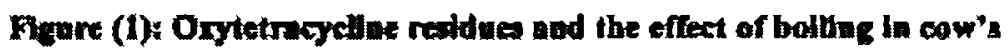

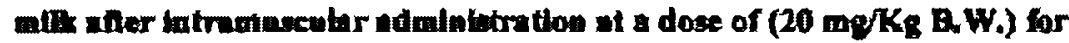
three wucesestre days

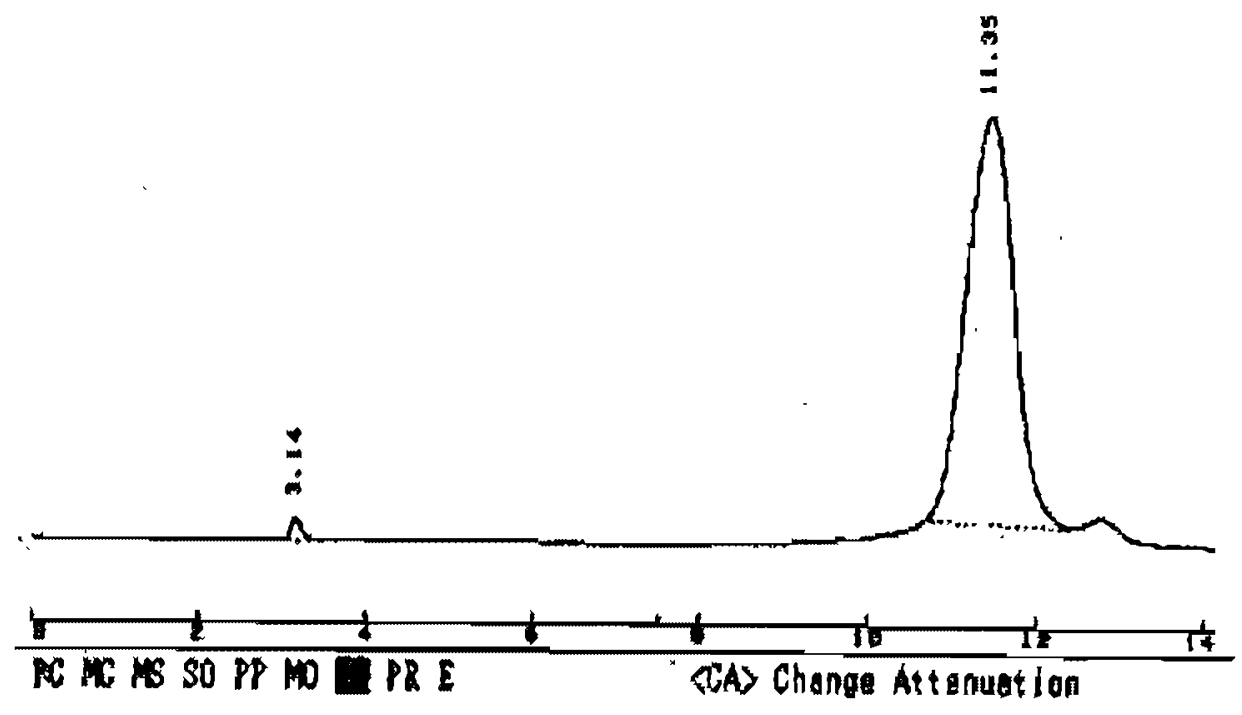

Figure (2): Chrommtograph of atondard oxytetracyelln (mg/m) 
Inona, O. Abori El inli; et al..

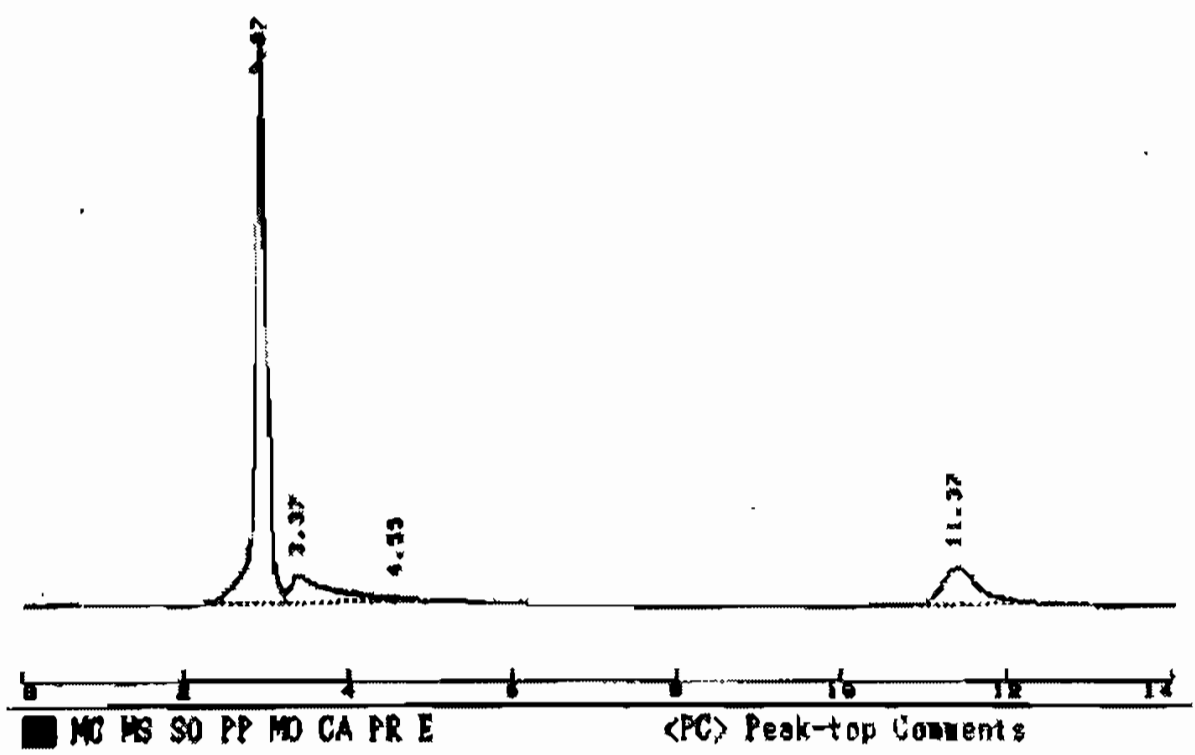

Pigure (B): Chromatogroph of oxytetracycliae concentrotion ne/ml of milk after $24 \mathrm{hr}$ from frat day of dritg adainistration

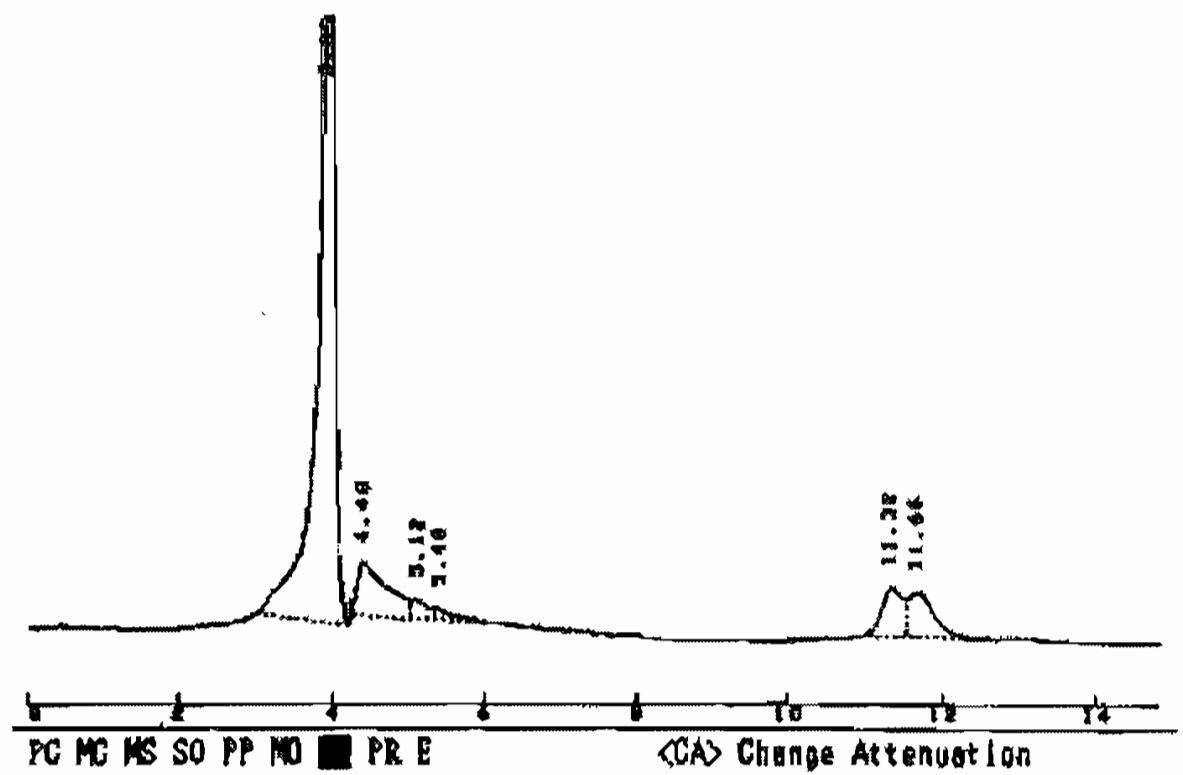

Pigure (4): Chronintograph of orytetracycllo concentratlok after bolling of milk at 24 br from drag admintration. 


\section{REFLRENCES}

Abd EL-Allm, A.; Whout, A.i Amer, M. 8.; Moheen، A. Wafin, H.; Abd-Alla and Naggh. a. Edrees. (1994): Enfecl of blology and pasteurbation as a safeguard against peniclilin residues In cow's milk 6th Sct. Cong. Fac. Vel. Med. Asslul, pp. 49-55.

Ad, A and Fullam, A M. (1EOA) : Effect of cooking procedure on axytetracycline res! dues in lamb muscle. I Agrid Food Chem. 42 (2561-2563).

AOAC. (1697) : International. Gadthcrburg 16, vol. 2, Chapter 33, Pp. 43-47.

Both, J. M. (1882) : Antblotic residue in milk. In. Pract. 4: 1500-109.

Botooglan, N. A. and Fotourle, D. J. (2001) : drug residues and public health, In drug residues in roods Marcel Dekker, Inc. New York, Basel, p. 269-295.

Brookets, P. (1920) : Chcmical cardno genesis, Br. Med. Bull.، 36.

Capalongo, Fi Santl, A Tomod, L. AnJoast, P. Miruaga, M. and Montesdera, C. (2002) : Residues of oxytetracycline and its 4, epimer in edlble tsasues from turkeys. J. AO. AC. Int: edible tissues from turkeys. J. AO. AC. Int. 85(1): 8-14.

Clnquilax, F. L.; Longo, D. B.; Barehl D.; Faplalo, A; Barebl, R. and Cozxanl, R. (2007) : Comparative pharmacokdnetics of oxytetracycline in goat and sheep milk. Vla Appla Nuora n. 1411, 00178 Rome. Italy.
Clubb, 8. L. (1986) : In: Clinical Avign medicine and surgery. "Text book" 2nd ed Edited by Greg: J.H and Ldida. R.H. Jowatst Uriv. Annes Press, USA.

Dina, O. A and Arowolo R. O. A (1991): Some eonsiderations on velermany drug 11 he and supply In Nigeris. Re. d. Filewge Merl. Vut pays Troptcaux. 44:29-31

DInsmore, P.; Sterens, R.; Cattell M.; Salwan, M. and Bundloh, S. (1986) : Oxyle. tracycline rcsidues in milk of cows treated for retalned plaeentas vet, Med. Assn. Nov. 15. Vol., 209. no, 10. p. 1753

Dipeolu and Along D. O. (2002) : rcsldtues of streptomycin antibtotic in meat sold for human consumption some statcs of SW Nigerta Arch 300tex -51:477-480.

El-Sherblni, M.; Abdel-khalek, A. and EGaml, A. (2003) : The effeet of temperature on vetertnary antlbiotlc. Residues and their no metabolites in inllk and some dalry prod. usts. Food hyglene and Central Rexp. Fat of veterinary Med. Mansoura University Animal Health Research Institulc. Mansoura.

Food Apriculture organization / world health organization FAO / WHO (1999) ; Evaluatton of certain veterinary during resldues in food forty seventh reports of joint FAO/WHO expert committee on frod additive pp.50-55.

Hnmann. J. A; Talle, $A$ and Heechen. w. (1978) : Anublotic and sulfonamides. In: Residues in mik and products pp44-70 Document 99. International Dajty Feederation 41 . 
Square Vergate, B.1040, Brussels, Belglum.

Heeschen, W. and Harding F. (1985) : Contaminants. In: Milk quality. F Harding (ed) pp 133-158.

Eubbert, W. T., Hagstad, H. V.; Spargler, E.; Alnton, H. M. and Hughes, K. L. (1996) : Food produetion technology milk processing. In: Food safety and Guallty Assuranee 2nd ed. Towa state. Univ. Ames Press. USA, pp 93100 .

Jaeques, Gerand, Mri Jan Schouten, L.i Harry V. E. and Henk, 8.; et al.s (1998) : Testing of raw milk for tetracycline resldues. J. Datry Scl 81: 2341-2345.

Jarunee, L. (2002) : The effect of heallng on Multuple resddues of tetracyelines in milk. Thamma Sat Int. J. SC. Teeh. vol 7. No. 3 September, December.

Jensed, R. G. (1895): Contamination in boylne milk in: Hanbook of milk composition. pp. 887-801. Aeademdc Press. Ine.

Konecy, 8. (1978) : Effect of temperature and ume on reduction of the binlogical activity of some kunds of anublouc in milk. Vetemarstvi 28: $409-410$.

Kunek, G,: Milko, K. and Blakowska, M. (1982) : occurrence of pendollin and other inhibltory substances in raw and retall milk in Gdansk provtnce. Poland. Medycyna Wctery Mary)na. 98(5): 232-235.

Kurtttu, J.; Fonnberg, S.; Virta, M. and Korp. M. (2002): Sensitive liquid chromato- graphic-mass spectrometer assay for norllaxacin in poultry tissues. $J$ Chromatog. B. Analyt. Teehnol. Blomed. Füfe Sel. 772(1): 185 189.

Martln, D. P. M,; Gomcz, J. Reuvers and Marcos. (1896) : RaPiD screening and confirmatory method for sulfonamides residucs in milk. In proceeding of the European residues conference mother land. $7(5): 865-891$.

Pavlina. J.; Dudglkora, E. V. A; Jozef Eokal, Jozef Nagy, Dlonyz Mate. (2003) : Determination of oxytetracycline residucs in milk with the use of HPiC method and two mleroblological inhibition assays. Bui]. Vet. Inst Pulawy 47, 211-216.

gnifade, A A and Babatude, G M. (1988) : Comparattve response of broller ehicks to a high nber diet supplement with four antiblotie. Anlmal feed sclence and technology. 64: 337-342-Antiblotle.

Rule, R. Moreno, L.i Serrano, J. M.i Roman, A G.: Moynano, R. and Garela. $J$. (2001) : Pharnacokinetics and resldues In milk or oxytetracyelin administered parenterally to dalry goats. Aust. Vet $J \times 79(7)$ : 492-96.

Schetbdex V. G. (1972) : Occurrence and decompostion of antbiotle in meat. Monatashreft fur Veternar Medieln Heft: 24 39.

Schollibaum, M. (1990) : Antlblotic therapy and resldue in dellvered milk. Antiblotic atherople and Ruckst and in der Ablle rerungsmilch swiss vet. $7(8): 7 \cdot 9$. 
Shahanl, K. M., (1987) : The effect of heat and vtory on the stabllity of Aureomyctin in milk. J. Dalry SC. Vol. 40 pp 289.296.

Thoma日, B. B. (1894) : Veterinary druy therapy "text book" 5th Ed.. Lea and Febiger. Awauerly Company Press, USA.

Tropllo, J.: saule, M. and Lescyznakn, K.
(1885) : Effect of hoat treatment on penicillin G In milk. Medycyna water ynaryjn a $41: 21$ !. 212.

Uno, K. (2002) : Oxytelracycline and oxa linic acld residues in kuruma prawn (penacus Japontcus) and effect of cooklng procedure on the residues. Shokuhin. Elselgakw. Zasshl 43 (2): $62-67$. 